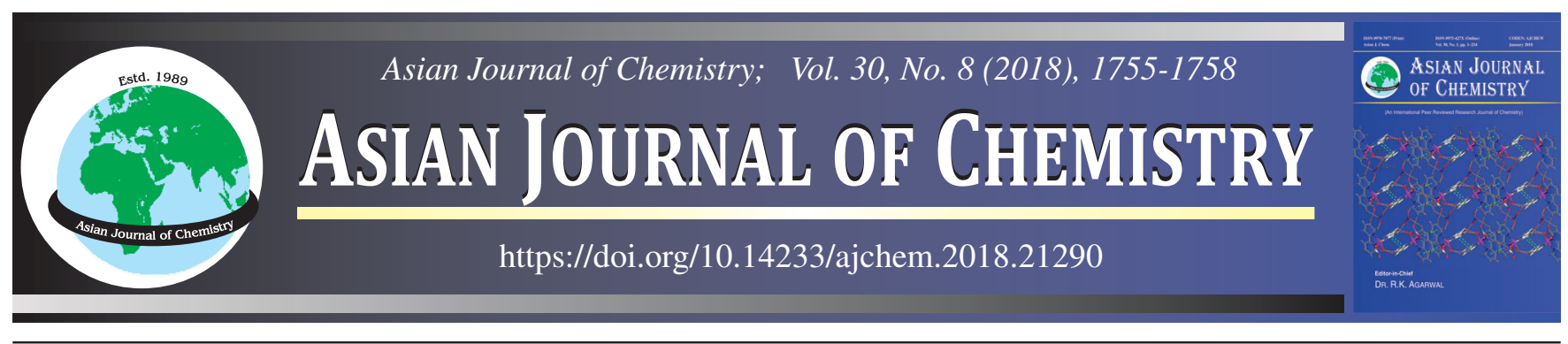

\title{
Enzymatic Synthesis of Epoxidized Fatty Hydrazides from Epoxidized Palm Oil Using Native Muchor meihei Lipase in $n$-Hexane Solvent
}

\section{Z. JAMINGAN ${ }^{1, *}$, W.M.Z.W. Yunus ${ }^{1,2}$, O.K. KHIM ${ }^{3}$ and N. AbDULlaH ${ }^{3}$}

${ }^{1}$ Faculty of Defence Science and Technology, National Defence University of Malaysia, Sg Besi Camp, 57000 Kuala Lumpur, Malaysia ${ }^{2}$ Centre for Tropicalization, Universiti Pertahanan Nasional Malaysia, Kem Sungai Besi, 57000 Kuala Lumpur, Malaysia

${ }^{3}$ Centre for Defence Foundation Studies, Universiti Pertahanan Nasional Malaysia, Kem Sungai Besi, 57000 Kuala Lumpur, Malaysia

*Corresponding author: E-mail: zakiahjamingan@yahoo.com

Received: 15 February 2018;

Accepted: 12 April 2018;

Published online: 30 June 2018;

AJC-18969

Epoxidized fatty hydrazides have been synthesized through an enzymatic catalytic synthesis reaction of epoxidized palm oil with hydrazine monohydrate by native Muchor meihei lipase enzyme in $n$-hexane solvent. Optimum reaction conditions were studied by observing the yield of epoxidized fatty hydrazides production using several parameters. The highest production of epoxidized fatty hydrazides was obtained when reaction temperature was $50{ }^{\circ} \mathrm{C}$ with an addition of $5 \%$ of enzyme to catalyze the reaction. This were accompanied using stirring speed of $165 \mathrm{rpm}$ under $24 \mathrm{~h}$ of reaction. The epoxidized fatty hydrazides was further characterized using Fourier transform infrared spectroscopy, nuclear magnetic resonance spectrometry and CHN elemental analyzer.

Keywords: Enzymatic synthesis, Epoxidized palm oil, Fatty hydrazides.

\section{INTRODUCTION}

Hydrazides have received a lot of attention due to their unique properties. They are valuable starting materials and intermediates to produce anionic surfactants [1], ionic surfactants [2,3], ligands [4], plastic additive [5,6] and also as a corrosion inhibitors [7]. In addition, due to their suitability on the biological and environmental activities, hydrazides can also be used as an antimicrobial agent [8] and also as an antituberculosis agent $[9,10]$. Furthermore, the structure of the hydrazides itself, which consists of multifunctional group such as an amide, an amine and a long alkyl chain in the molecular structure, leads to a chemically reactive molecule that can favour many organic synthesis reactions.

There are various methods that have been developed to synthesize hydrazides, either by using chemical methods [11-13] or enzymatic methods [14-17]. Chemical method generally requires multiple steps that start with heating of corresponding oils or esters with hydrazine hydrate in a basic condition for a few hours. Through this chemical synthesis of reaction process, it is found to be costly, requiring multiple steps, requiring high pressure and temperature, time consuming and also producing unwanted byproduct [18]. Enzymatic synthesis of hydrazides has become a good alternative way to produce hydrazides. This is because enzymatic synthesis offers many advantages such as having no by-products produced at the end of reaction, the potential of being done in milder condition compared to using chemical method and also being more reaction selective [18]. Furthermore, this kind of technique is also known as less intensive of energy usage, as it does not require high temperature and pressure and also avoids the formation of byproducts [18].

In enzymatic synthesis reaction, many types of enzyme have been studied. The most common type of enzyme used for organic reaction is lipases (triacylglycerol hydrolases, EC.3.1.1.3). Lipases have good properties to be used in organics synthesis reaction such as high stability in organic solvent, can be cofactor-independent and insoluble in the organic media as well [19] and also demonstrating high enzymatic activity at organic media [20]. Other than that, lipases also have properties such as stereo-selectivity, chemoselectivity and regio-selectivity so that it is widely used for biocatalyst in various reactions [21].

Based on the literature review, no studies have been carried out to synthesize epoxidized fatty hydrazides directly from epoxidized palm oil using enzymatic method. Therefore, in this study, fatty hydrazides will be synthesized directly from epoxidized palm oil with hydrazine monohydrate using native Muchor meihei lipase as an enzyme. The use of native muchor meihei lipase in this study is due to its good performance under mild reaction condition. Various conditions parameters during catalytic synthesis of epoxidized fatty hydrazides will be monitor such as temperature, dosage of enzyme used, stirring speed and the reaction time. Characterization of the synthesized product will 
be characterized using Fourier transform infrared spectroscopy, nuclear magnetic resonance and $\mathrm{CHN}$ elemental analyzer.

\section{EXPERIMENTAL}

Epoxidized palm oil was supplied by Advance Oleochemical Technology Division (AOTD) of Malaysian Palm Oil Board. Hydrazine monohydrate of reagent grade (65-64\% purity) and phosphorus pentoxide was supplied by Sigma Aldrich and used as received. Analytical grade $n$-hexane was purchased from Fisher Scientific and ethanol from Merck Company whereas, native Muchor meihei lipase was supplied by Creative Enzymes (New York, USA).

The product was analyzed by using FTIR spectrometry, in the range of 4000-300 $\mathrm{cm}^{-1}$ using (Perkin Elmer-Spectrum BX Fourier transform infrared) spectrometer instrument equipped with an attenuated total reflectance. The structure of the product was reconfirmed using $1 \mathrm{H}$ NMR spectrometry (Bruker 600 $\mathrm{MHz}$ ). Meanwhile, nitrogen content in epoxidized fatty hydrazides was analyzed by using a LECO Elemental Analyzer 932).

Synthesis of epoxidized fatty hydrazides: The synthesis reaction was carried out by mixing $1 \mathrm{mmol}$ epoxidized palm oil with $12 \mathrm{mmol}$ of hydrazine monohydrate in a $100 \mathrm{~mL}$ conical flask containing $n$-hexane in the presence of enzyme. The mixture was then transferred into water bath at different conditions based on the parameters of the study. The parameters involve were (a) temperature, (b) stirring speed, (c) dosage of the enzyme and (d) reaction time. Once the reaction period was completed, the white paste formed was transferred into a bigger conical flask, mixed with ethanol and heated at $60-70{ }^{\circ} \mathrm{C}$ for $15 \mathrm{~min}$. This is to ensure that the enzyme was separated from the clear solution. The free enzyme solution was left for $3 \mathrm{~h}$ at $28{ }^{\circ} \mathrm{C}$ to let it precipitate. The white precipitate was further filtered using a Whatman 4B filter paper in Buchner funnel under a reduced pressure and dried under reduced pressure in the presence of phosphorus pentoxide. This method was a modified procedure as described earlier $[11,14,15]$.

\section{RESULTS AND DISCUSSION}

Variation of reaction conditions were found to have significant effect on the production of epoxidized fatty hydrazides. Determination of optimum reaction condition will help us to understand the system.

Effect of temperature: In order to identify the optimum temperature for enzymatic synthesis of epoxidized fatty hydrazides, the enzyme activity of native Muchor meihei lipase was screened over the reaction temperature ranging from 30 to $60^{\circ} \mathrm{C}$. The yield of epoxidized fatty hydrazide increase linearly as the temperature increase from 30 to $50^{\circ} \mathrm{C}$ (Fig. 1). At $30^{\circ} \mathrm{C}$, the yield of epoxidized fatty hydrazide was $233.9 \mathrm{mg}, 455.5 \mathrm{mg}$ was achieved at $40{ }^{\circ} \mathrm{C}$ while $609.2 \mathrm{mg}$ of epoxidized fatty hydrazide was produced at $50^{\circ} \mathrm{C}$. However, as the temperature increase above $50^{\circ} \mathrm{C}$, the yield drops slightly to $519.2 \mathrm{mg}$. Therefore, the optimum temperature for hydrazides production is $50{ }^{\circ} \mathrm{C}$. These trends of optimum temperatures for the lipase catalyzed reactions were usually observed using enzyme which is isolated from the fungus family. It is already reported that the optimum temperature for synthesis of organic compounds using lipases from fungus Mucor family was between 45 and $55^{\circ} \mathrm{C}$ [22], $40{ }^{\circ} \mathrm{C}[14,15], 50$ to $60^{\circ} \mathrm{C}$ [23] and $60^{\circ} \mathrm{C}$ [24]. The differences of optimum reaction temperature also mainly depend on the type of immobilization nature of the enzyme itself and where they fixed on. Furthermore, from Fig. 1, the yield of epoxidized fatty hydrazides decreased at higher temperature, possibly due to the nature of enzyme itself. Structure of the enzyme will begin to disrupt at higher thermal energy, causing low enzymatic catalyzed activity. Thus, resulting to the decreased amount of epoxidized fatty hydrazides yield [25].

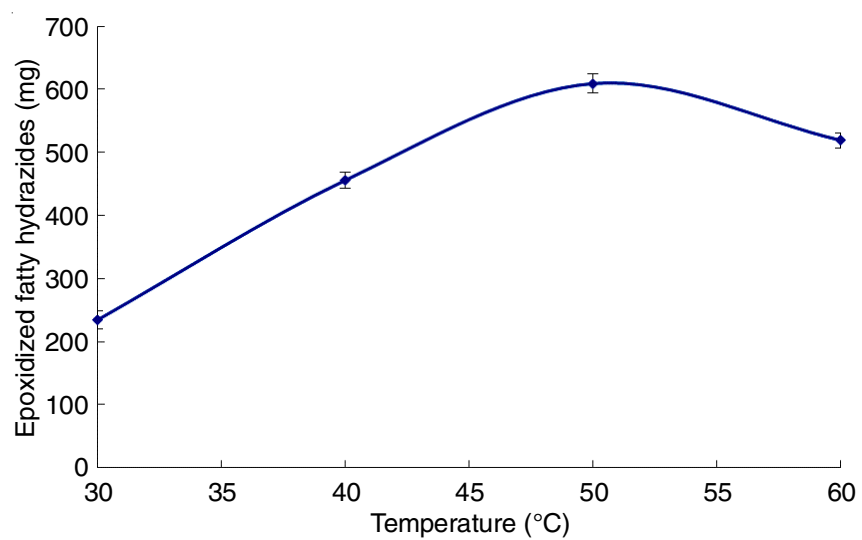

Fig. 1. Effect of temperature on the yield of epoxidized fatty hydrazides production (condition of reaction: $24 \mathrm{~h}, 165 \mathrm{rpm}, 5 \%$ of enzyme used, $n$-hexane as a solvent)

Effect of amount of enzyme: Amount of enzyme used to catalyze reaction is one of the main factors to get the highest yield of hydrazides with the usage of minimal amount of catalyst. Interesting trend was observed from Fig. 2. Production of epoxidized fatty hydrazide can still occur without addition of enzyme to catalyze the reaction. With the use of enzyme, we found that the yield of epoxidized fatty hydrazides increased significantly from 262.4 to $609.2 \mathrm{mg}$ with the increasing amount of enzyme 1 up to $5 \%$, respectively. However, further increase on the amount of enzyme into the system, yields of epoxidized fatty hydrazide started to decrease. Similar findings were observed by Ismail et al. [18]. This information indicates that the increased amount of catalyst load will lead to higher catalytic activity results in formation of acyl-enzyme complexes [26] and further increase the formation of hydrazides. Hereby, the yield started to decrease because the huge amount of active site of the enzyme was not fully exposed and remained inside the bulk enzyme

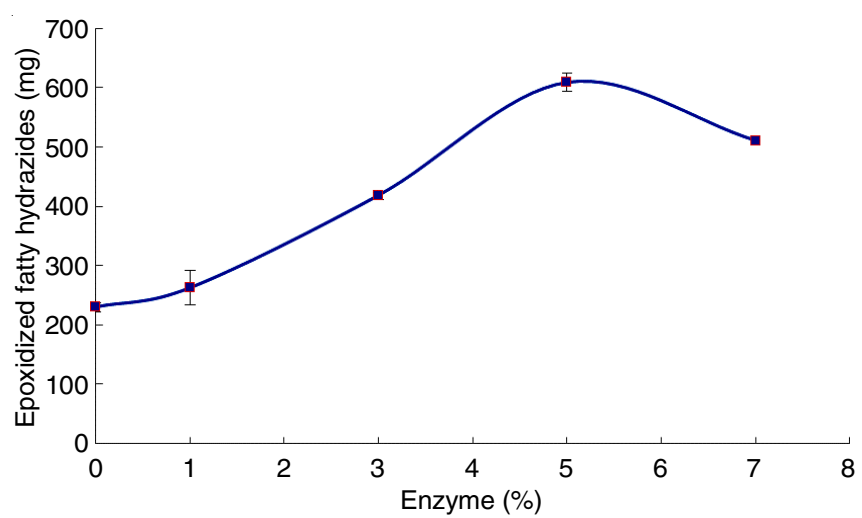

Fig. 2. Effect of enzyme on the yield of epoxidized fatty hydrazides production (condition of reaction: $24 \mathrm{~h}, 50{ }^{\circ} \mathrm{C}, 165 \mathrm{rpm}, n$-hexane as a solvent) 
and did not contribute to any other reactions that can cause to the increased amount of the yield of hydrazides [27]. This implies that the presence of excess enzyme in the system affect the catalytic activity of reaction.

Effect of reaction time: Fig. 3 shows the effect of reaction time on the yield of hydrazides. The yields rapidly increased from $98.9 \mathrm{mg}$ for $3 \mathrm{~h}$ to $609.2 \mathrm{mg}$ for $24 \mathrm{~h}$ reaction time and then, become constant virtually after $24 \mathrm{~h}$ of reaction time. At the early stage of reaction, the collision between substrate and enzyme was done in a limited time or in the kinetic regime. The chances for the conversion of epoxidized palm oil to epoxidized fatty hydrazides were not highly significant. However, when the reaction period remained longer and up until $24 \mathrm{~h}$, the reaction was done in optimum period or in diffusion limiting regime and it reached their equilibrium state. As a result, further increase of reaction time did not affect the product yield.

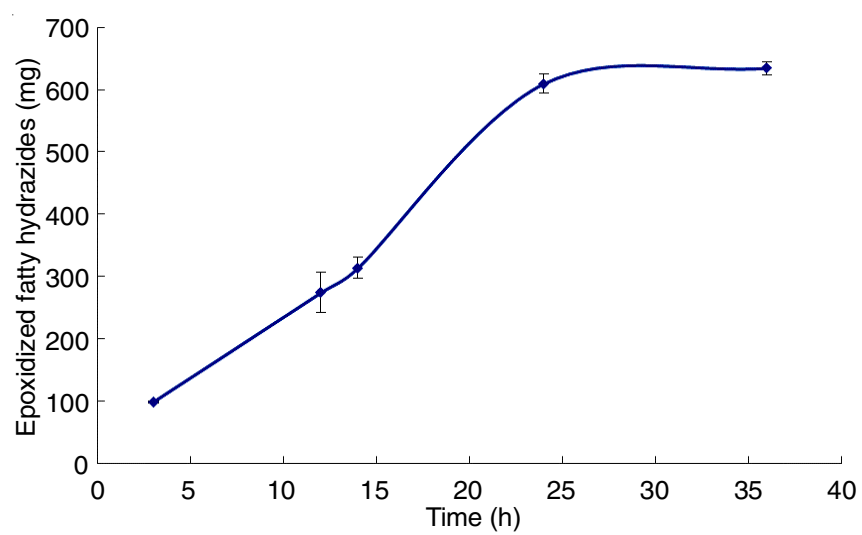

Fig. 3. Effect of reaction time on the yield of epoxidized fatty hydrazides production: (Reaction condition : $165 \mathrm{rpm}, n$-hexane as solvent, $5 \%$ of enzyme, $50{ }^{\circ} \mathrm{C}$

Effect of stirring speed: Stirring speed of waterbath shaker was also taken into consideration, because it plays the major role that can boost up the reaction. The speed was set between 130 to $200 \mathrm{rpm}$ based on the operation limit of the shaker itself. Fig. 4 shows the effect of reaction speed on the yield of hydrazides. It was found that the yield was increased from 561.4 to $613.3 \mathrm{mg}$ with the increasing of speed from 130 to 200 $\mathrm{rpm}$, respectively. However from 165 to $200 \mathrm{rpm}$, the increment of the yield was not clearly significant which is $609.2 \mathrm{mg}$ at the stirring speed of $165 \mathrm{rpm}$ and $613.3 \mathrm{mg}$ at stirring speed of $200 \mathrm{rpm}$. This observation showed that the reaction at $165 \mathrm{rpm}$ was already enough to get a high yield of epoxidized fatty hydrazides.

Characterization of epoxidized fatty hydrazides: The functional groups of epoxidized palm oil and epoxidized fatty hydrazides synthesis at highest yield $(609.2 \mathrm{mg})$ with reaction condition $\left(50{ }^{\circ} \mathrm{C}\right.$ reaction temperature, $5 \%$ amount of enzyme used, $165 \mathrm{rpm}$ stirring speed and at $24 \mathrm{~h}$ reaction time) were determined using FTIR spectrometry (Fig. 5). FTIR spectra of epoxidized palm oil showed C-O-C epoxide group stretching vibration at $839 \mathrm{~cm}^{-1}$. This observation is almost similar with Cheing et al. [28]. They found C-O-C streching from oxirane vibration of epoxidized palm oil in the range of $950-850 \mathrm{~cm}^{-1}$ and at $1250 \mathrm{~cm}^{-1}$ which is usually weak and overlays with other peaks [28]. Other than that the strong absorption peak

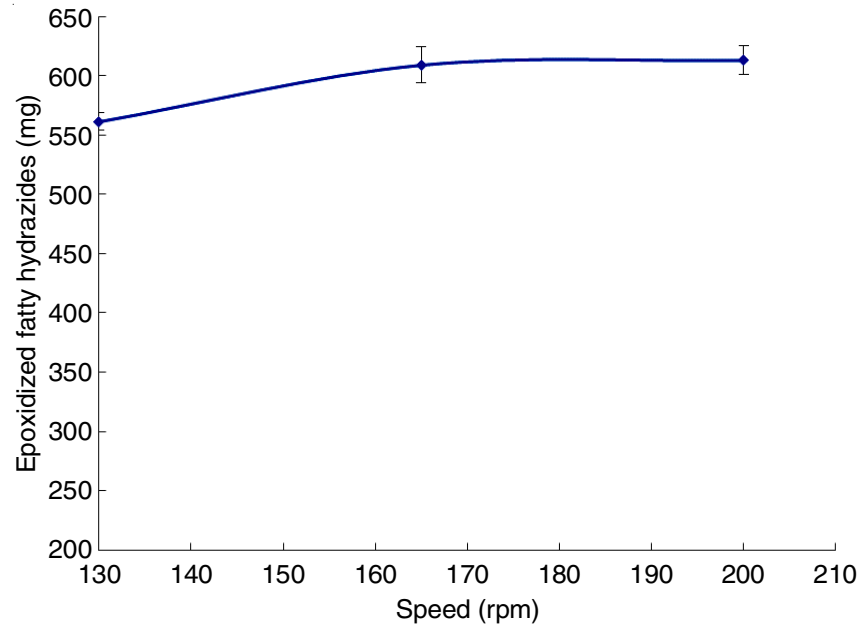

Fig. 4. Effect stirring speed on the yield of epoxidized fatty hydrazide production (condition of reaction: $24 \mathrm{~h}, n$-hexane as solvent, $5 \%$ of enzyme, $50{ }^{\circ} \mathrm{C}$ )

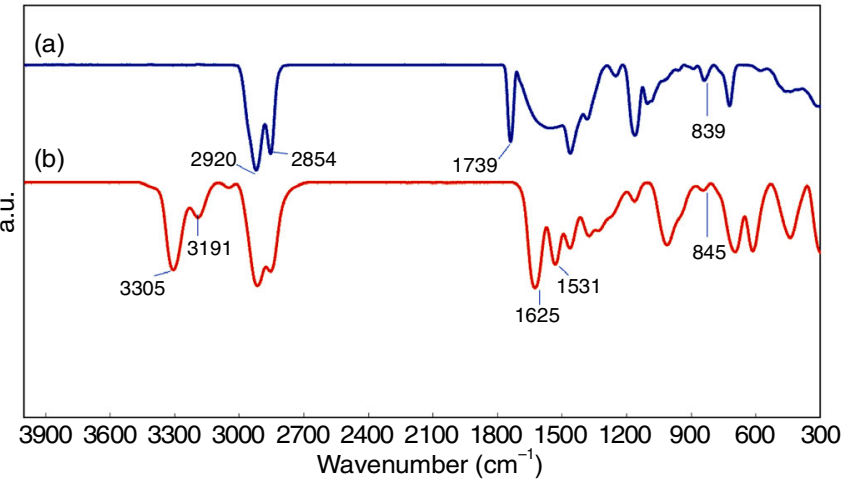

Fig. 5. FTIR spectra of (a) epoxidized palm oil and (b) epoxidized fatty hydrazides at optimum reaction condition

for $\mathrm{C}=\mathrm{O}$ of carbonyl group attached at epoxidized palm oil structure was spotted at $1739 \mathrm{~cm}^{-1}$. Then, a strong absorption band at $2920 \mathrm{~cm}^{-1}$ belongs to the $\mathrm{C}-\mathrm{H}$ stretching of terminal methyl group of the triglyceride chains, while peak at 2854 $\mathrm{cm}^{-1}$ was due to the $\mathrm{C}-\mathrm{H}$ symmetric stretching in the saturated fatty acid backbone.

The resulted epoxidized fatty hydrazides were analyzed and monitored by the presence of few important peaks. Firstly, the peak at the region of 3305 and $3191 \mathrm{~cm}^{-1}$ was due to asymmetrical and symmetrical N-H of primary amine. On the other hand, the stretching of $\mathrm{C}=\mathrm{O}$ of amide group was observed at $1625 \mathrm{~cm}^{-1}$ and $\mathrm{N}-\mathrm{H}$ bending of the primary amine appeared at the frequency of $1531 \mathrm{~cm}^{-1}$. The peak of C-O-C of epoxide group was observed to remain after $24 \mathrm{~h}$ of reaction with lower intensity at $845 \mathrm{~cm}^{-1}$ compared to the original epoxidized palm oil. Overall, the important peaks were appeared at epoxidized fatty hydrazides spectrum indicates the hydrazinolysis reaction taken place and the product was successfully synthesized.

NMR analysis: The presence of epoxy group, proton $\mathrm{N}-\mathrm{H}$ and $\mathrm{NH}_{2}$ was reconfirmed by comparing the chemical shift for epoxidized palm oil and epoxidized fatty hydrazides spectra as shown in Fig. 6a-b. From these figures, proton $\mathrm{NH}_{2}$ in the epoxidized fatty hydrazides structure was present in the region of $3.70 \mathrm{ppm}$, while the $\mathrm{N}-\mathrm{H}$ of amide group was observed at the region of $6.81 \mathrm{ppm}$. This peak was observed at low ppm 

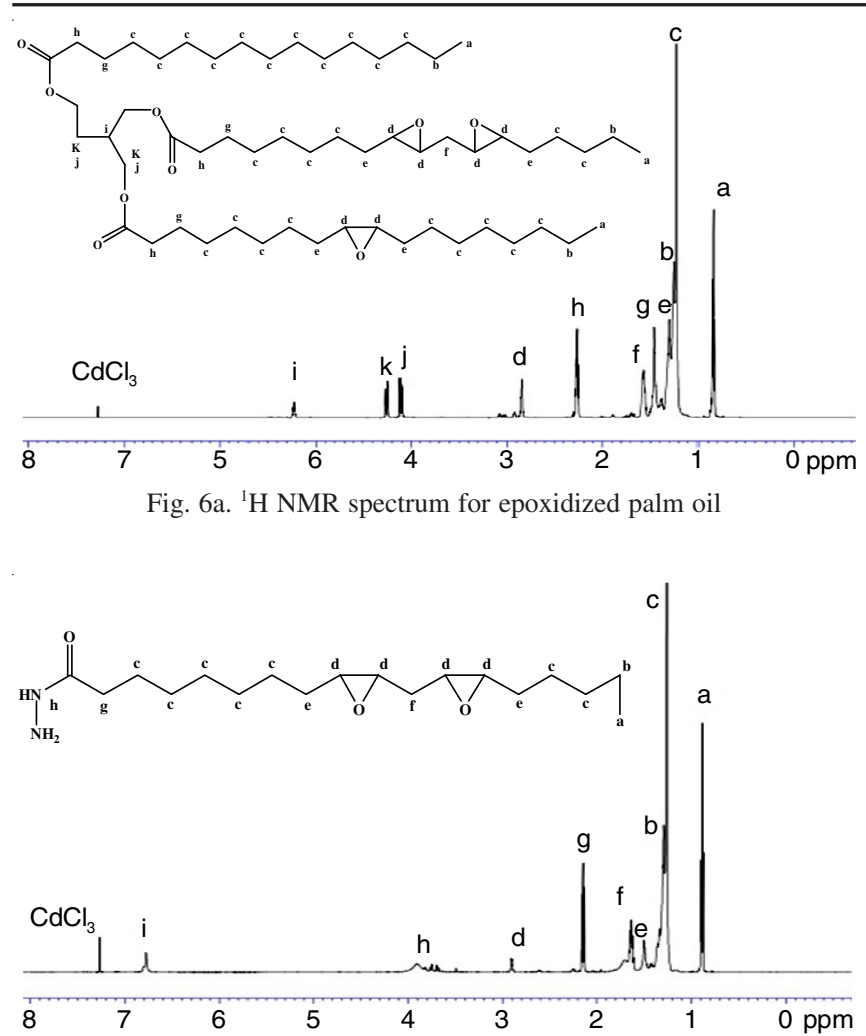

Fig. 6b. ${ }^{1} \mathrm{H}$ NMR spectrum for epoxidized fatty hydrazides at optimum reaction condition

compared to the study conducted by other researchers [11]. This might be due to the difference in solvents used, temperature, concentration and other reasons which can lead to the difference in the actual ppm value but still in the range of $5.00-9.00 \mathrm{ppm}$ [29]. Other than that, peak at $2.90 \mathrm{ppm}$ was attributed for proton attached at the epoxy group. The observation from the spectrum suggests that the epoxy group from epoxidized palm oil was still being preserved after the hydrazinolysis reaction was completed and the addition of amide and amine group was successfully introduced in the structure.

In addition, $\mathrm{CHN}$ elemental analyzer also used to analyze the presence of the nitrogen contents in the products, which is one of the signs of the formation of the epoxidized fatty hydrazides. The content of the nitrogen was found to be $9.92 \%$ indicated that the epoxidized fatty hydrazide was successfully synthesized during the reaction process.

\section{Conclusion}

This study shows that epoxidized fatty hydrazides has been sucsessfully synthesized directly through enzymatic method. The product was further characterized using FTIR spectroscopy, NMR spectrometry and CHN elemental analyzer. From overall data analysis, it was found that the optimum condition for preparing the epoxidized fatty hydrazides at $50^{\circ} \mathrm{C}$, with $5 \%$ of enzyme, $165 \mathrm{rpm}$ speed of reaction and $24 \mathrm{~h}$ of reaction period.

\section{ACKNOWLEDGEMENTS}

The authors thank Ministry of Higher Education Malaysia (MOHE) for funding this study through research grant Fundamental Research Grant Scheme (FRGS/2/2014/SG05/UPNM/01/1).

\section{REFERENCES}

1. M.F. Amine, A. Eissa, A. El-Sawy, A. Shaaban and R. El-Sayed, Grasas Aceites, 55, 370 (2004).

2. A. Eissa, Kozmetika, 51, 155 (2002).

3. E. Badr, E. Kandeel and B. El-Sadek, J. Oleo Sci., 59, 647 (2010); https://doi.org/10.5650/jos.59.647.

4. V. Mahalingam, N. Chitrapriya, M. Zeller and K. Natarajan, Polyhedron, 28, 1532 (2009); https://doi.org/10.1016/j.poly.2009.03.023.

5. A. Samimi and S. Zarinabadi, Int. J. Sci. Investig., 1, 43 (2012).

6. A.S. More, T. Lebarbé, L. Maisonneuve, B. Gadenne, C. Alfos and H. Cramail, Eur. Polym. J., 49, 823 (2013);

https://doi.org/10.1016/j.eurpolymj.2012.12.013.

7. P. Kumari, P. Shetty and S.A. Rao, Int. J. Corros., 2014, 1 (2014); https://doi.org/10.1155/2014/256424.

8. X.H. Liu, Y.-X. Shi, Y. Ma, G.-R. He, W.-L. Dong, C.-Y. Zhang, B.-L. Wang, S.-H. Wang, B.-J. Li and Z.-M. Li, Chem. Biol. Drug Des., 73, 320 (2009);

https://doi.org/10.1111/j.1747-0285.2009.00779.x.

9. G.D. Yadav, S.S. Joshi and P.S. Lathi, Enzyme Microb. Technol., 36, 217 (2005);

https://doi.org/10.1016/j.enzmictec.2004.06.008.

10. A. Manvar, A. Malde, J. Verma, V. Virsodia, A. Mishra, K. Upadhyay, H. Acharya, E. Coutinho and A. Shah, Eur. J. Med. Chem., 43, 2395 (2008); https://doi.org/10.1016/j.ejmech.2008.01.016.

11. E. Al-Mulla, W. Yunus, N. Ibrahim and M. Rahman, Res. J. Appl. Sci., 3, 545 (2008).

12. W.H. Hoidy, M.B. Ahmad, E.A.J. Al-Mulla, W.M.Z.W. Yunus and N.B. Ibrahim, J. Oleo Sci., 59, 15 (2010); https://doi.org/10.5650/jos.59.15.

13. E.A.J. Al-Mulla, W.M.Z.W. Yunus, N.A.B. Ibrahim and M.Z.A. Rahman, J. Oleo Sci., 59, 157 (2010); https://doi.org/10.5650/jos.59.157.

14. S. Mohamad, W. Yunus, M.J. Haron and M. Rahman, J. Oleo Sci., 57, 263 (2008); https://doi.org/10.5650/jos.57.263.

15. T.I.T. Noor Maznee, A.H. Hazimah, W.Y.W. Md. Zin, J. Oleo Sci., 61, 297 (2012); https://doi.org/10.5650/jos.61.297.

16. H. Jahangirian, M.J. Haron, S. Silong and N.A. Yusof, J. Oleo Sci., 60 , 281 (2011); https://doi.org/10.5650/jos.60.281.

17. E.A.J. Al-Mulla, W.M.Z.W. Yunus, N.A.B. Ibrahim and M.Z.A. Rahman, J. Oleo Sci., 59, 59 (2010); https://doi.org/10.5650/jos.59.59.

18. N.M.T. Ismail, H.A. Hassan and W.M.Z.W. Yunus, Google Patents (2016).

19. A. Zaks and A.M. Klibanov, Proc. Natl. Acad. Sci. USA, 82, 3192 (1985); https://doi.org/10.1073/pnas.82.10.3192.

20. P.E. Sonnet and G.G. Moore, Lipids, 23, 955 (1988); https://doi.org/10.1007/BF02536343.

21. L.A. Nelson, T.A. Foglia and W.N. Marmer, J. Am. Oil Chem. Soc., 73, 1191 (1996); https://doi.org/10.1007/BF02523383.

22. K. Gulyamova and K. Davranov, Chem. Nat. Compd., 31, 372 (1996); https://doi.org/10.1007/BF01165205.

23. N. Handayani, K. Loos, D. Wahyuningrum, Buchari and M.A. Zulfikar, Membranes, 2, 198 (2012); https://doi.org/10.3390/membranes2020198.

24. D. Montent, M. Pina, J. Graille, G. Renard and J. Grimaud, Lipid/Fett, 91, 14 (1989); https://doi.org/10.1002/lipi.19890910104.

25. M. Romero, L. Calvo, C. Alba, A. Daneshfar and H. Ghaziaskar, Enzyme Microb. Technol., 37, 42 (2005); https://doi.org/10.1016/j.enzmictec.2004.12.033.

26. C. Torres, C. Otero and I.I.I. Part, Enzyme Microb. Technol., 29, 3 (2001); https://doi.org/10.1016/S0141-0229(01)00344-1.

27. N.N. Gandhi, S.B. Sawant and J.B. Joshi, Biotechnol. Bioeng., 46, 1 (1995); https://doi.org/10.1002/bit.260460102.

28. B.W. Chieng, N.A. Ibrahim, Y.Y. Then and Y.Y. Loo, Molecules, 19, 16024 (2014); https://doi.org/10.3390/molecules191016024.

29. D. Pavia, G. Lampman, G. Kriz and J. Vyvyan, Introduction to Spectroscopy, Cengage Learning, edn 4 (2009). 